\title{
The Hague Convention 1961: Solution of Foreign Public Document Legalization for Indonesia and ASEAN Member Countries
}

\author{
BAMBANG HARTOYO ${ }^{*}$ \\ DR. FAUZIAH MOHD. NOOR ${ }^{2}$ \\ ${ }^{* 1} \mathrm{Ph}$.D Candidate of Universiti Utara Malaysia (UUM), Malaysia \\ ${ }^{2}$ Senior Lecturer, College of Law, Government and International Studies \\ (COLGIS), UUM, Malaysia \\ *(b_hartoyo2001@yahoo.com)
}

This journal is licensed under a Creative Commons Attribution-NonCommercial 4.0 International License (CC-BY-NC).

Articles can be read and shared for noncommercial purposes under the following conditions:

- BY: Attribution must be given to the original source (Attribution)

- NC: Works may not be used for commercial purposes (Noncommercial)

This license lets others remix, tweak, and build upon your work non-commercially, and although their new works must also acknowledge you and be non-commercial, they don't have to license their derivative works on the same terms.

License Deed Link: http://creativecommons.org/licenses/by-nc/4.0/

Legal Code Link: http://creativecommons.org/licenses/by-nc/4.0/legalcode

$A B C$ Research Alert uses the CC BY-NC to protect the author's work from misuse.

\section{Abstract}

The main discussion of this study is why Indonesia and some ASEAN member countries so far have not participated as contracting state to The Hague Convention 1961 (Apostille Convention). This leads to the situation that anyone who needs the legalization of public documents to be used abroad, he/she must go through repeated legalizations to various institutions of the respective authorities. This is not only time consuming and costly to individual or corporate who requires the legalization, but also hinder the respective government's program to enhance foreign direct investment to their own country. The objective of this study, therefore, is particularly to encourage Indonesia as well as ASEAN member countries to become a contracting state to The Hague Convention 1961. This qualitative study is conducted based on the observation on some Indonesian representatives overseas, as well as on notary offices of Indonesia. Literatures and scientific studies from Indonesia and overseas, as well as interviews with high-rank officials of the Ministry of Foreign Affairs of Indonesia, and diplomats from Indonesian representatives abroad are also used and conducted to fulfill the objective comprehensiveness of this study. This study eventually provided some suggestions that Indonesia as well as ASEAN member countries would immediately take action to become contracting state to The Hague Convention 1961.

\section{Keywords}

Foreign Public Document, Public Document Legalization, Public Policy Reform, The Hague Convention 1961, Apostille Convention.

\section{INTRODUCTION}

The abolition of legalization for foreign public documents is stipulated in The Hague Convention of 5 October 1961 (The Convention abolishing the Requirement of legalization for Foreign Public Documents was signed in The Hague on 5 October 1961) hereinafter will be 
referred as The Hague Convention 1961 or Apostille Convention. The Hague Convention 1961 is basically to simplify the legalization of public documents to be used by the people amongst countries.

Currently, the process of legalization of foreign public documents in some countries (including Indonesia) is quite time consuming and costly to individual or corporate. Anyone who needs a public document legalization to be used in another country, after a document authenticated by local public office or Notary, then it needs another legalization from the Ministry of Justice. Document that has been validated by the local Ministry of Justice, then shall be legalized again by the Ministry of Foreign Affairs of the respective country.

Furthermore, before the document to be used in the destination country, the document needs to be re-legalized by the respective Embassy or Consulate General.

Gautama (2005: 63), in this context, stated that such a legalizing process is not only inefficient, but also impractical as it requires legalization process repeatedly. The inefficient and impractical such legalization for foreign documents is actually not necessary.

To overcome the complicated and repeatedly such a legalization procedure, The Hague Conference formed The Convention of 1961 which determines that 'Apostille' is used to abolish the requirements for foreign public documents. Legalization in the form of Apostille is generally required on official or public documents to be used in other country, such as:

(a) Marriage Certificate,

(b) Documents of Commerce,

(c) Contract or Business Agreement,

(d) Certificate of Land,

(e) A birth certificate, even including

(f) Certificate or Diploma, etc.

Except Brunei Darussalam, no more of ASEAN member countries participating as contracting state of the Hague Apostille Convention 1961. As a matter of fact, Apostille is expected to also be a solution for ASEAN member countries to simplify the procedure or the legalization of public documents for their citizen or for their corporate who will use the public document in other countries. As for ASEAN member countries, in particular, this is needed as all the member states have committed to implement ASEAN Economic Community (AEC) principles in the AEC Blue Print 2025. The AEC Blueprint 2025 consists of five interrelated and mutually reinforcing characteristics, namely:

(i) A Highly Integrated and Cohesive Economy;

(ii) A Competitive, Innovative, and Dynamic ASEAN;

(iii) Enhanced Connectivity and Sectoral Cooperation;

(iv) A Resilient, Inclusive, People-Oriented, and People-Centered ASEAN; and

(v) A Global ASEAN.

\section{THE HAGUE CONVENTION 1961}

The Hague Convention 1961 is basically a simplification of foreign documents legalization procedure that previously regarded as a complicated one. The procedure of legalization of foreign documents to be used in other countries, was requiring a process that is not simple, take 
times and quite costly. To find a solution, the Hague Conference on Private International Law then welcomed the proposal of the Council of Europe to draft the Convention.

After holding several meetings and discussions since April 1959, the First Commission of the Ninth Session of the Conference, chaired by Mr. A. Panchaud, a Judge of the Swiss Federal Court, with Mr. R. Glusac, First Secretary at the Ministry of Foreign Affairs of Yugoslavia as Vice Chairman, and Mr. G. Droz of the Permanent Bureau of the Conference, as Drafting Secretary start the drafting. The Commission finally completed its task and submitted the draft to the Plenary Session of The Hague Conference. In the Plenary Session on October 5, 1961, The Hague Conference accepted and approved the draft. It was then concluded to become the Hague Convention of 5 October 1961 (Convention abolishing the Requirement of Legalization for foreign public documents).

The important point stipulated in The Hague Convention 1961 is mentioned in Article 1 which states:

The present Convention shall apply to public documents which have been executed in the territory of one Contracting State and which have to be produced in the territory of another Contracting State.

This means that the Apostille applied to public documents which have been made in the state parties shall be recognized and implemented in another contracting state.

It was also stated in the Convention that the definition of public documents are:

a) Documents emanating from the courts, including the public prosecutor;

b) Administrative documents;

c) Notarial acts;

d) Official certificates which are placed on documents signed by persons in their private capacity, such as official certificates recording the registration of a document or the fact that it was in existence on a certain date and official and notarial authentications of signatures.

However, the Convention excludes or does not apply to:

a) To documents executed by diplomatic or consular agents;

b) to administrative documents directly dealing with commercial or customs operations.

In this context, thus, the Convention does not apply to the documents issued by the Embassy or Consulate of a represented country. In other words, an official document issued by the Embassy or Consulate of the respective country, shall be accepted as official document as it is and no more legalization needed. The same treatment, applies as well to the documents issued directly related to trade (commercial) and customs.

One thing stipulated in The Hague Convention 1961 is in Article 4 of which determines to use the title of "Apostille (Convention de La Haye du 5 October 1961)" in French on each Apostille stamped on the document. 
In addition, article 4 also mentions that the Certificate referred to in Article 3 may be in the form of "Allonge". Basically the usage of Apostille and Allonge is more or less the same, which is a confirmation or authentication of what stated in the document. The difference between the Apostille and Allonge is, Apostille used generally in the form of a stamp chopped on the document, while Allonge is usually a separate piece of paper attached describing or authenticating the commercial document.

\section{SAMPLE OF APOSTILLE AND ALLONGE:}

\section{a) Apostille:}

\begin{tabular}{|c|c|}
\hline \multicolumn{2}{|c|}{$\begin{array}{l}\text { APQSTILLE } \\
\text { [Comenton del La Haye du } 5 \text { ootobre 1so1] }\end{array}$} \\
\hline 1. Country: & Un Ged Kingdom of Great Britain and Worthern lreland \\
\hline \multicolumn{2}{|c|}{ 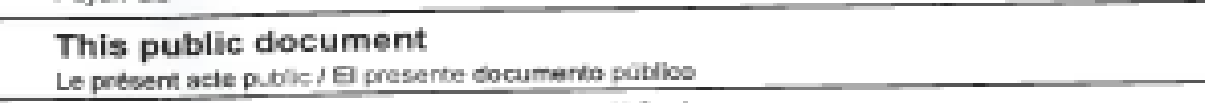 } \\
\hline $\begin{array}{l}\text { 2. Has been signed by } \\
\text { a etd signes } \\
\text { ha eids limide por }\end{array}$ & Marish Fe sind \\
\hline 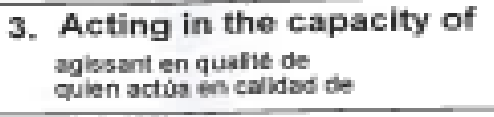 & Hohary Puble \\
\hline 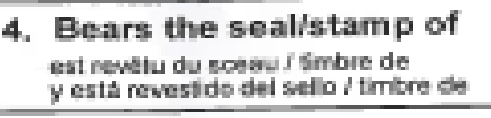 & Tha Said Rolary Publo \\
\hline \multicolumn{2}{|c|}{$\begin{array}{l}\text { Certified } \\
\text { Anecte I Centieado }\end{array}$} \\
\hline 5.ation London & 6. the 14 January 2013 \\
\hline Her Majesty' & $\begin{array}{l}\text { ncipal Socretary of State for Foraign and } \\
\text { Commommalth Affairs }\end{array}$ \\
\hline $\begin{array}{l}\text { 8. Number } \\
\text { acus nu flusp el numere }\end{array}$ & J496298 \\
\hline 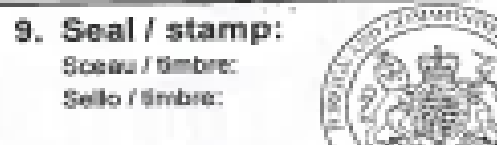 & 10. Signatufe: J. Cascy \\
\hline
\end{tabular}

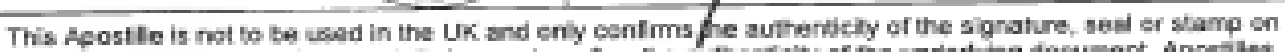

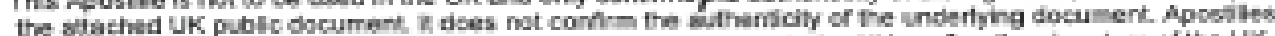

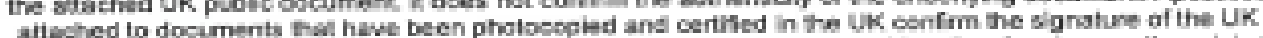

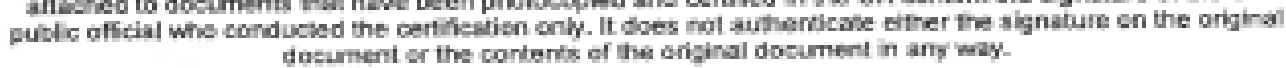

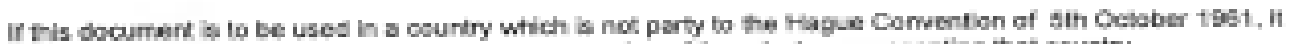

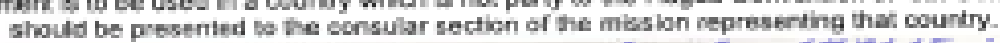

Sample of Apostille of the Kingdom of Great Britain. 


\title{
b) Allonge:
}

\author{
B A N K OF N E V A D A \\ 14635 North Kieland Blvd., Suite 201 \\ Scottsdale, AZ 85254
}

Office (480) 609-5500 Fax (480) 609-5569

\section{ALLONGE TO NOTE}
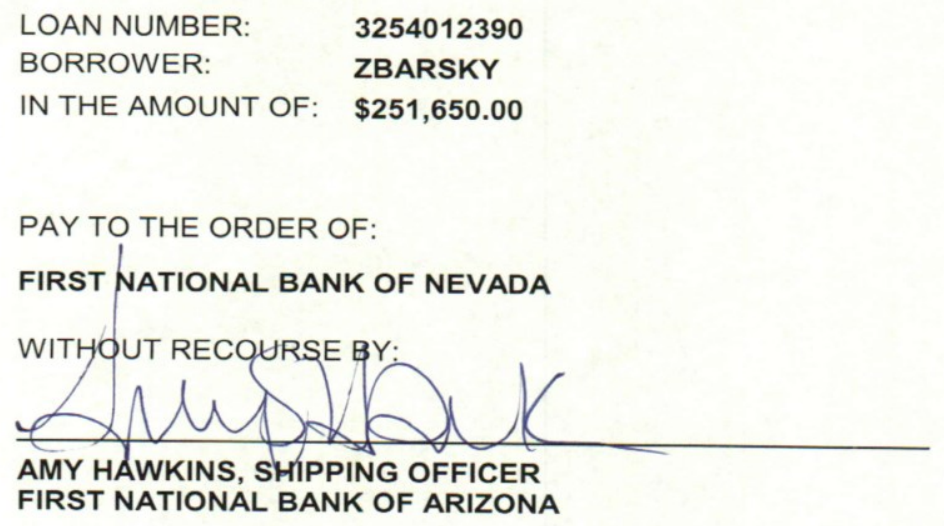

PAY TO THE ORDER OF:

HSBC Bank USA as Trustee under the applicable agreement

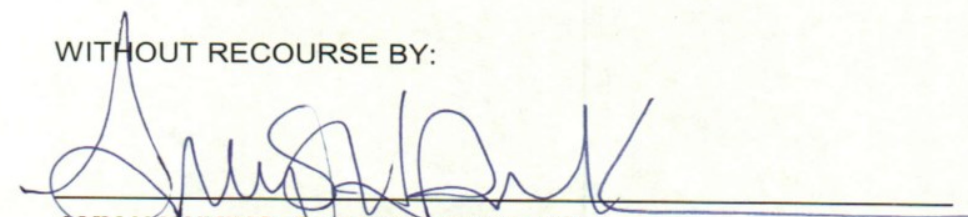

AMY HAWKINS, SHIPPING OFFICER

FIRST NATIONAL BANK OF NEVADA

Sample of Allonge.

\section{RESPONSE OF INTERNATIONAL COMMUNITY}

The Hague Convention was formed in 1961 as a solution to make ease or simplify the process of legalization of foreign public documents repeatedly. To facilitate their citizens or corporates in using the public documents to other countries, therefore, most countries have participated as signatory state or contracting party to the Hague Convention1961. 
Knowing the importance of The Hague Convention 1961 as a solution of the complicated process of legalization for foreign documents, as of December 20, 2017, as many as 115 countries have become contracting states to The Hague Convention 1961.

European countries are the most who have become contracting states of The Hague Convention 1961. Therefore, all 28 member countries of the European Union have become Contracting States of The Hague Convention in 1961. While American countries which have become Contracting States are: Argentina, Brazil, Chile, Costa Rica, Ecuador, Montenegro, Panama, Paraguay, Peru, Suriname, USA, Uruguay and Venezuela.

The most questioning in terms of not being a contracting state to The Hague Convention 1961 is Canada. Being one of the major countries in North America, so far Canada has yet to become Contracting State. The official website of the Government of Canada only says that Canada is not a Contracting State of The Hague Convention 1961. Therefore, all documents to be used in Canada must obtain legalization through the Embassy or Consulate of Canada in the country of origin. One reason mentioned in their website is that (in some cases) apparently because the misplacement or misuse of the Apostille on the document.

On the other side, Australia and New Zealand have become contracting states as well. Asian countries that have become state parties are Azerbaijan, China, India, Israel, Japan, Republic of Korea, and Turkey. Of the whole world, countries of Africa are the least, namely only Mauritius, Morocco and South Africa.

In the meantime, the member countries of ASEAN or contracting state to the Convention so far is Brunei Darussalam only. In this connection, some experts of Private International Law of Indonesia have raised this issue. Prof. Sudargo Gautama is one of them. He was not only a professor, but also a (business) lawyer. Therefore the reason why he raised about the importance of ASEAN countries, Indonesia in particular, to become a party to The Hague Convention of 1961, among others, is to facilitate the authentication of documents used in legal (business) disputes in the court.

Beside Prof. Gautama, there is also another international law expert, namely Prof. Zulfa Djoko Basuki. Prof. Basuki in this case focuses more on the process of accession if a country needs to become a state party to The Hague Convention 1961. She says that if the procedur to become a contracting state to the Hague Convention 1961 will take time, it is advised to do it through accession. This was delivered on a paper presented at a seminar "Forum of the Harmonization of National and International Law in National Law Development Board (BPHN) of Indonesia on March 25, 2013.

Meanwhile The International Chamber of Commerce (ICC) in a publication dated 23 January 2013, has made an appeal to countries who have not become a contracting state to The Hague Convention 1961 to immediately participate. Furthermore, the ICC also urges the contracting states to accept and endorse the efforts that have been developed by the Hague Conference in the form of electronic Apostille parties as part of the electronic Apostille Program (e-APP). 


\section{EXCESSES OF THE HAGUE CONVENTION 1961}

Implementation or the use of Apostille in authenticating the public document is not without any problem. Apostille stipulated in The Hague Convention 1961, on one hand, simplifies in terms of the process of legalization of public documents to be used in other countries. On the other hand, however, it also contains a weakness that can be considered as abuse of the authority. The misuse that has been considered as a problem is the use of Apostille as the attestation for diplomas issued by certain colleges or universities that are not accredited in the respective state.

In some cases this has occurred in the United States. As indicated by Alan L. Contreras in one of his findings that the Apostille was also misused by one of the Colleges that are not accredited in the United States. Apparently, it is also seen as "the tip of the iceberg". In other words, there are a lot of similar cases have arisen. Sadly, it happened not just in the United States, but also in some other countries.

Furthermore, it is worried that Apostille misuse also applies to un-original documents or fake documents. This could happen if the respective Ministry or Embassy who put the Apostille do not thoroughly check the authenticity and the content of the document submitted by certain party who requested an Apostille, but just simply sign and put the stamp on the document. In addition, it is also questionable whether or not the agency that issued the document is a legitimate institution based on the respective local law.

In responding to those abuses or misuse of the Apostille, The Hague Conference again discussed these issues in February 2009. The results of the discussions, then The Hague Conference issued a circulation stating that the Agency who put Apostille should include the words stating that it only certifies the signature in the document. This means that the Agency (Ministry or Embassy) who stamps the Apostille does not guarantee for the authenticity of the document and its contents.

\section{APOSTILLE AND ASEAN ECONOMIC COMMUNITY (AEC)}

ASEAN Economic Community (AEC) is basically a manifestation of the spirit of the ASEAN member countries to integrate economic cooperation. Although it is not free from political nuance, AEC was also set up in anticipation of free trade amongst its member countries. This include trade in goods and traffic of commodities and services.

AFTA (ASEAN Free Trade Area) was launched in 1992. AFTA itself was originally set up as an economic cooperation and integration among ASEAN member countries on the trade of commodities. AFTA agreement was also followed with some agreements to create a wider market not only on trade of commodities, but also for services as well as investment, skilled labor and to generate capital flows more freely.

As to Indonesia, Rahayu (2005) in Hartono \& Setyowati (2009) said that foreign direct investment is one of the main agenda of the Government. In line with Rahayu, Saparini (Steering Executive Centre of Reform on Economics / CORE) in Wangke (2014) also stressed that attracting investment is also one that needs to be anticipated by the Government in the era of the ASEAN Economic Community (AEC). On the other hand, although initially targeted 
that AEC will begin in 2020, but later it was moved forward to 2015 (Narjoko \& Wicaksono). Meanwhile, Tambunan (2006) mentioned that one of the obstacles in attracting foreign direct investment in Indonesia is bureaucracy. Bureaucracy here was seen in the context of the process of licensing of which, in some cases, so far is still not simple and convoluted in terms of time processing. In this context, it is including the legalization of foreign documents.

\section{THREATS OR CHALLENGES AND OPPORTUNITIES}

SWOT is a theory in management of which, among others, interpreted that managing and developing an organization, from time to time is necessary to identify of the Strengths, Weaknesses, Opportunities and Threats of the organization.

In other words, SWOT is needed to analyze any internal or external factors are owned or faced to develop and improve an organization, whether it is a business entity or a government agency. Strengths considered as a power, or any positive factors that is owned by an organization. This power need to be upgraded or strengthened from time to time in order to develop the business. Weaknesses meant that the management of the organization needs to identify the weaknesses or deficiencies to be fixed. The agency should also identify any Opportunity both internally and externally that can and should be utilized. While Threats interpreted as identifying any threats oe negative factors that need to be anticipated in order to make the organization survived or even more developed. On the other hand, Threats should also be intended as identification of any factor that can be used as a challenge to improve and develop the business.

There are some challenges for the member countries of ASEAN in responding to the AEC. This challenge, particularly for countries whose their economic infrastructure is not ready or not as good as the other member countries. These threats can be either; the entry of foreign capital into one of the member countries more freely, penetration of foreign banks, the development of foreign companies to open branches in other countries, the rivalry existence of local companies and foreign companies and the influx of foreign workers. This kind of foreign workers is not seen only for the skilled workers, but more worrisome by local workers is if they are offering a cheaper salary. The entry of foreign commodities especially those with cheaper price, is also another threat, etc.

As for member countries whom are betterly prepared in terms of economic infrastructure and more organized or more modernized, AEC will be both a challenge and an opportunity. They can see the opportunities, for example: the transfer of technology that they can adopt from more advanced countries, the challenge for the skilled person to work in other country to earn bigger salary and better benefits, opportunity for a local company to develop its business or open branches in other countries, and a challenge for developing countries to export local products to other more developed countries, etc.

\section{DEREGULATION AND DE-BUREAUCRATIZATION}

This paper does not intend to discuss deepenly on the AEC and its influences in economy to member countries. Instead, this will focus more on the efforts or what can be done by an ASEAN member country in responding to its threats, challenges and opportunities. It is the intention of this paper that the ASEAN member countries should take any beneficial action they can do in addressing to the implementation of the AEC. 
Deregulation and de-bureaucratization, among others, are important factors in responding the threats, challenges and opportunities. Actions that can be considered to be implemented are:

(a) To make and maintain a political and economic stability, so that investors are interested to invest in a country.

(b) Encouraging employers not only the large ones, but also the small and medium enterprises to expand their export markets.

(c) Removing the high economic costs, especially for exporting procedure.

(d) Simplifying and streamlining procedures and processes for skilled person to work overseas.

(e) Improving the economic infrastructure to make it more attractive to invite foreign capital or foreign direct investment.

(f) Facilitate the process of investment in order to be more quickly, more efficient, etc.

This means that bureaucracy of which is still slow and rambling in a certain area need to be cut. Regulations that hinder investment are also to be simplified. As for entrepreneurs who want to develop their export abroad, the procedure should be made simpler.

Simplification on legalization of foreign public documents, as one factor, should also be implemented. It should be encouraged as well in order to make local entrepreneurs more rapidly in dealing transactions with their business partners abroad. While for foreign investors who want to invest their capital in a country, the regulation also needs to be simplified.

It has been reviewed that the legalization of foreign documents is time consuming process and costly, esp. for countries that are not yet participated as a contracting state to the Hague Convention 1961. This will happen particularly to entrepreneurs who will make business deals with their partners abroad. It will apply as well for foreign investors who will invest their capital or develop their businesses in an ASEAN member country.

The Hague Convention 1961, therefore, is one of the solutions or alternatives to overcome all the obstacles. The process of legalization of foreign documents that is complicated, time consuming and costly is simplified by providing Apostille on any document to be used abroad. The more of ASEAN member countries to become the contracting states of The Hague Convention of 1961, not only will make its citizens easier to do any personal business abroad, but also to make a better climate to the entrepreneurs or investors dealing and developing their business in other countries, vice versa.

\section{CONCLUSION}

a. The process of legalization of foreign public documents, previously requires a process of legalization or authentication repeatedly from several authorized institutions in order for a document can be used in other country. Such a process is not only takes time, but also costly.

b. This will happen not only to any citizen of a certain country who will use their document for personal matter but also to entrepreneurs who will make dealing for their business with their counterparts abroad or to expand their business in other countries. 
c. After several meetings of which quite time consuming since 1959, The Hague Conference made a solution to the problems of legalization for foreign document by establishing the Hague Convention 1961 (The Convention abolishing the Requirement of legalization for Foreign Public Documents was signed in The Hague on 5 October 1961).

d. On October 5, 1961, The Hague Convention 1961 finally agreed. The Hague Convention in 1961 with an Apostille is basically a simplification of the process of legalization of foreign documents previously repeated and impressed complicated. In other words, Apostille is a solution to make any citizen or any corporate that require legalization or authentication and will use the document abroad according to their respective purposes.

e. Apostille is also expected to serve as a means to facilitate an ASEAN member country in the process of legalization of foreign documents in order to attract foreign direct investment. On the other hand, by simplifying the process of legalization of documents, Apostille can also serve to increase and expand exports of the ASEAN member to other countries.

f. Apostille stipulated in The Hague Convention 1961 since October 5, 1961, or more than 50 years ago. However, there is none of the ASEAN member countries has participated as a party or a contracting state of the Convention. Given the important role of The Hague Convention 1961 in facilitating and simplifying the process of legalization of foreign documents, it is expected that ASEAN members shall immediately consider it to participate as a signatory country and ratify The Convention.

g. Apostille is not just one way to ease the ASEAN member countries in promoting and expanding opportunities for exporting of local products to other countries, but also in simplifying the process of attracting foreign investment procedures to any member country.

h. Although Apostille provides convenience and simplification, the success of any ASEAN member countries in attracting foreign investment and expand their exports to other countries is determined by other variable factors in improving a country's economy and industry.

\section{References}

ASEAN Economic Community.https://asean.org/asean-economic-community/ Retrieved 17 July, 2018.

The Hague Convention 1961 (Apostille Convention). Number of Contracting Parties to this Convention: 115. https://www.hcch.net/en/instruments/conventions/status-table/?cid=41. Retrieved 17 April 2018.

Webster's, Encyclopedic Unabridged Dictionary of the English Language (1994), New rev. Ed. New Jersey: Random House Value Publishing, Inc.

Garner, Bryan A. (2004), Black's Law Dictionary, Eighth Edition, St. Paul: West Publishing Co. Dallas, Texas.

Council of the Notariats of the European Union. "Comparative Study on Authentication Instruments: National Provisions of Private Law, Circulation Mutual Recognition and Enforcement, Possible Legislative Initiative by the European Union" (PDF). http://www.pedz.uni-mannheim.de/daten/edzma/ep/08/EST23673.pdf Retrieved 27 May 2017.

Gautama, Sudargo. (2005). Indonesia dan Konvensi-Konvensi Hukum Perdata Internasional (Indonesia and Conventions of International Civil Law), Third Edition, Cet. 2, PT. Alumni, Bandung.

Zulfa Djoko Basuki (2013). KEMUNGKINAN INDONESIA MENGAKSESI THE HAGUE CONVENTION ABOLISHING THE REQUIREMENT OF LEGALIZATION FOR FOREIGN PUBLIC DOCUMENTS. (The possibility of INDONESIA accessing THE HAGUE CONVENTION abolishing the Requirement of Legalization for Foreign Public Documents) http://www.bphn.go.id/data/documents/prof-zulfa-makalah.pdf. Retrieved September 28, 2016. 
ICC urges ratification of Apostille Convention for simplified authentication of public documents. http://cciwa.com/docs/international-trade/international-trade-talk-23-january-2013.pdf?sfvrsn=2. Retrieved September 28, 2016.

Alan L. Contreras (2003). Ross University: Cash Cow or Pig in a Poke? Center for International Higher Education, A Quarterly Publication. Campion Hall, Boston College, Chestnut Hill, MA 02 467, USA.

Black's Law Dictionary (2004: 105). Apostille: a marginal note or observation; esp. a standard certification under the Hague Convention for authenticating documents used in foreign countries. While in Webster's (1994: 71) Apostil or Appostille: a marginal annotation or note.

James W. Adams, Jr. The Apostille in the 21st Century: International Document Certification and Verification. Houston Journal of International Law, Summer 2012.

Hartono, M. Edi. \& Setyowati, Milla S. (2009). Hubungan Insentif Pajak dengan Iklim Investasi bagi Perusahaan Penanaman Modal Asing di Sektor Industri Tekstil di Indonesia (Relations between Tax Incentives for Foreign Investment with the Climate of Investment in Textile Industry Sector in Indonesia). Journal of Administrative Sciences and the Organization Jan-Oct 2009, p. 8. Vol. 16, No. 1.

Wangke, Humphrey. (2014). Peluang Indonesia Dalam Masyarakat Ekonomi ASEAN 2015 (Indonesia Opportunities in ASEAN Economic Community 2015). Journal of International Affairs Vol. VI No. 10.

Narjoko, Dionysius A. \& Wicaksono, Teguh Y. Achieving the ASEAN Economic Community Agenda: an Indonesian Perspective. Centre for Strategic and International Studies, Indonesia. London School of Economics, UK.

Tambunan, Tulus. (2006). Iklim Investasi di Indonesia: Masalah, Tantangan dan Potensi. (Investment Climate in Indonesia: Problems, Challenges and Potential Factors). Kadin-Indonesia - Jetro.

Ahmad Reza Ommani (2011). Strengths, Weaknesses, Opportunities and Threats (SWOT) analysis for farming system management businesses. African Journal of Business Management Vol. 5 (22), pp. 9448-9454, 30 September, 2011.

Creola Johnson (2006). CREDENTIALISM AND THE Proliferation OF FAKE DEGREES: THE EMPLOYER TO NEED A DEGREE pretends; THE EMPLOYEE pretends TO HAVE ONE. Hofstra LABOR \& EMPLOYMENT LAW JOURNAL. Volume 23, No. 2, 2006.

Evelyn Chiyevo GARWE (2015), Qualification, Awards and Recognition Fraud in Higher Education in Zimbabwe. Journal of Studies in Education ISSN 2162-6952 2015, Vol. 5, No. 2.

Conclusions and Recommendations OF THE SPECIAL COMMISSION ON THE PRACTICAL OPERATION OF THE HAGUE apostille, SERVICE, TAKING OF AND ACCESS TO JUSTICE Evidence Conventions (2 to 12 February 2009). Hague Conference on Private International Law. https://assets.hcch.net/upload/wop/jac_concl_e.pdf Retrieved 1 September 2016.

Chia Siow Yue (2013), The ASEAN Ēconomic Community: Progress, Challenges, and Prospects. Asian Development Bank Institute, No. 440 October, 2013. 